\title{
PELAJARAN TERBAIK \\ AGAR SUKSES MERINTIS BISNIS PENDIDIKAN
}

\author{
Zidah Dwi Murtafaqo \\ Universitas Nahdlatul Ulama Sidoarjo
}

\section{PENDAHULUAN}

Startup bisnis pendidikan Anda dapat memenuhi harapan siswa ketika mereka mencari pelatihan yang efektif dan mudah untuk berbagai mata pelajaran. Banyak siswa tidak mampu mendapatkan pendidikan mahal dari universitasuniversitas mapan. Yang lain gagal mengikuti kelas reguler di kolase karena berbagai alasan. Bagi mereka, startup pendidikan Anda bisa datang sebagai sinar harapan. Meskipun ada persaingan ketat karena banyak lembaga pendidikan telah berlombalomba untuk mendapatkan bagian dari pasar ini, Anda masih bisa menjadi besar. Dunia wirausaha menjadi trendi karena tampilan kesuksesan yang menyilaukan (Purnomo et al., 2019). Dunia dan masyarakat membutuhkan kewirausahaan (Setyawati, Purnomo, Irawan, Tamyiz, \& Sutiksno, 2018).

Pendidikan adalah menyampaikan ilmu dan mentransformasi orang lain menjadi lebih baik (Fidiana, Istiana, Rosyidah, \& Purnomo, 2017). Prinsip pendidikan adalah sosial. Sebagai seorang guru, kita harus memiliki kepedulian sosial (Asitah, Usmawati, Rosyidah, \& Purnomo, 2017). Jadi, jika Anda siap untuk meluncurkan bisnis pendidikan dan mengubah startup Anda menjadi bermerek tahun ini, maka bacalah beberapa pelajaran terbaik dari mentor yang penting dan perlu diingat.

\section{BUAT PLATFORM SEKOLAH ANDA}

Pendidikan Indonesia membutuhkan peningkatan akses, mutu dan relevansi pendidikan untuk memberi manfaat membangun bagi pendidikan dan rakyat Indonesia (Irawan et al., 2018). Untuk melakukan ini, Anda harus menggunakan platform pengajaran online. Mereka akan membantu Anda meng-host video dan kursus Anda, dan menghemat banyak uang untuk mencoba melakukannya sendiri. Sebelum Anda memilih platform, Anda perlu bertanya pada diri sendiri pertanyaan tentang aksesibilitas. Bagaimana dan di mana Anda ingin sekolah Anda digunakan (Johnson, 2019).

- Apakah hanya browser?

- Apakah orang dapat mengaksesnya di ponsel dan perangkat mereka?

- Apakah orang akan dapat mengakses melalui televisi mereka, dengan aplikasi video OTT?

Tergantung pada sekolah yang ingin Anda jalankan, berbagai tingkat aksesibilitas akan diharapkan dari Anda. Sementara sekolah menggambar mungkin hebat dari 
peramban web, sekolah yoga mungkin perlu membaca televisi mereka. Masalah utama lain yang akan Anda hadapi dalam mendirikan sekolah Anda adalah bagaimana platform kursus bekerja. Banyak dari mereka hanya memungkinkan Anda untuk membuat kursus mandiri, dan Anda harus Frankenstein bersama untuk membuatnya menyerupai sekolah. Tetapi ada cara untuk membuat seluruh sekolah di mana siswa Anda dapat bergerak mulus dari bagian ke bagian. Lebih baik lagi, Anda dapat membuatnya tersedia di lebih banyak perangkat, dan melayani pelanggan Anda di mana Anda membutuhkannya (Johnson, 2019).

\section{PELAJARI KOMPETITOR}

Cari pesaing yang menawarkan produk atau layanan serupa ke target pasar Anda bisnis pendidikan. Persaingan mungkin bersifat lokal atau online, jadi pastikan untuk mempertimbangkan keduanya. Tentukan bagaimana mereka menentukan harga layanan mereka pelaku bisnis pendidikan, bagaimana menjangkau klien dan di mana mereka beriklan (Brookins, 2019).

\section{MEMBIAYAI BISNIS}

Setelah Anda menentukan visi dan tujuan Anda, sekarang giliran Anda untuk mulai menjalankan rencana. Untuk itu, modal adalah hal yang paling penting. Apa pun bisnisnya, ia membutuhkan sejumlah modal untuk memulai. Karena itu, Anda harus memutuskan bagaimana Anda akan mengumpulkan modal. Anda bisa mencari investor atau mengambil pinjaman dari bank. Itu tergantung pada jumlah uang yang bisa Anda keluarkan untuk bisnis Anda (Arya, 2019). Teknologi komputer telah menawarkan peluang baru dalam proses pembelajaran baik di ruang kelas, pembelajaran jarak jauh atau belajar mandiri (Simarmata et al., 2018). Hasil penelitian menunjukkan bahwa penerapan pembelajaran multimedia dapat meningkatkan prestasi siswa (Iskandar, Rizal, Kurniasih, Sutiksno, \& Purnomo, 2018).

\section{PILIH CARA DISTRIBUSI}

Setelah Anda menentukan subjek, Anda harus memikirkan bagaimana Anda akan memberikan kursus. Dengan kursus berbasis kelas, proses pengajarannya cukup mudah: Anda menyampaikannya secara langsung, dan dapat mendistribusikan dan menahan materi pelatihan sesuka Anda. Pendidikan daring sedikit berbeda, karena mengajar beberapa orang pada saat yang sama lebih sulit, dan akses ke sumber daya statis dapat dibagikan dengan orang-orang yang belum membayar untuk mereka. Layanan video online seperti YouTube atau Vimeo adalah salah satu opsi, dan konten pendidikan yang substansial sudah ada di platform ini. Namun, sebagian besar bisnis tidak dapat menghasilkan cukup uang dari pandangan saja. Sebagai gantinya, penyedia pendidikan online menaruh sebagian konten mereka di YouTube dan meletakkan sisanya di belakang paywall, atau memiliki strategi konten yang berbeda untuk YouTube untuk mengiklankan layanan mereka. Banyak situs 
pembelajaran bahasa misalnya fokus pada video yang menyenangkan seperti katakata kutukan atau frasa populer, dan menggunakan daya tarik viral dari video-video ini untuk membawa orang-orang ke dalam flip. Dimungkinkan untuk meng-host video secara pribadi untuk pelanggan di platform ini, tetapi itu tidak terlalu praktis. Meskipun tautan dapat tidak terdaftar - artinya tautan tersebut tidak muncul dalam fungsi pencarian - tautan tersebut berpotensi dibagikan oleh pelanggan yang Anda kirimi, memungkinkan orang lain untuk melihatnya secara gratis. Anda mungkin mengalami masalah yang sama jika Anda mengirim email kursus kepada pelanggan, seperti tautan unduhan untuk file PDF atau video. Meskipun orang umumnya 'membajak' lebih banyak dari situs web yang lebih besar daripada tutor individu atau situs kursus, Anda mungkin masih menghadapi risiko. Idealnya, Anda tidak akan mengizinkan pengguna untuk mengunduh materi kursus berbayar, alih-alih menempatkan mereka di balik paywall di situs web Anda (Eurostart Entreprises, 2015).

\section{CARI TAHU TARGET PELANGGAN}

Bisnis berkembang dengan melayani target pelanggan mereka. Mengambil isyarat dari ini, startup pendidikan Anda juga harus mengatasi masalah siswa target tertentu. Itulah resep untuk sukses. Jangan membuat kesalahan dengan menargetkan setiap bagian siswa. Secara umum, di AS, startup harus memberikan pendidikan kepada siswa miskin yang bersedia membayar Anda dengan biaya terjangkau. Di sisi lain, kelas perkotaan dan menengah memiliki pendapatan yang dapat dibuang dan mereka dapat membayar biaya mahal kepada lembaga pendidikan berkualitas tinggi yang telah mapan. Jadi, jangan menargetkan mereka, karena mereka tidak mungkin menjadi pelanggan Anda. Anda juga dapat menargetkan keluarga di negara miskin. Selain itu, Anda juga dapat menghubungi sekolah yang mencari eksperimen dengan teknik pendidikan baru (Ray, 2015). Manajemen adalah proses mengarahkan atau menjalankan bisnis, serta. sekelompok manajer atau direktur (Purnomo, Putri, \& Rosyidah, 2017). Siswa perlu memahami apa yang diketahui dan apa yang diminta untuk memiliki kemampuan menjawab (Suci et al., 2018). Implementasi teknologi pembelajaran adalah salah satu cara yang diperlukan untuk menunjukkan kompetensi lulusan yang berkualitas (Sudrajat et al., 2019).

\section{KESIMPULAN}

Pelajaran terbaik agar sukses merintis bisnis pendidikan adalah cari tahu target pelanggan, pilih cara distribusi, biaya bisnis, pelajari kompetitor, dan buat platform.

\section{REFERENCES}

Arya, N. (2019). Things to Consider While Starting an Educational Services Business. Retrieved December 9, 2019, from https://www.franchiseindia.com/education/things-to-consider-while-startingan-educational-services-business.12980 
Asitah, N., Usmawati, D. Z., Rosyidah, E., \& Purnomo, A. (2017). MI Hasyim Asy'ari IImu Harus Terus Mengarus. In Wirausaha Pendidikan Indonesia (Jilid 2). Sidoarjo: UNUSIDA Press.

Brookins, M. (2019). How to Start an Education Related Small Business. Retrieved December 10, 2019, from https://smallbusiness.chron.com/start-educationrelated-small-business-2239.html

Eurostart Entreprises. (2015). How to start an online education business. Retrieved December 12, 2019, from https://www.eurostartentreprises.com/business-advice/item/194-how-to-startan-online-education-business

Fidiana, W., Istiana, Z., Rosyidah, E., \& Purnomo, A. (2017). MINU Waru 2 Insan Berkilau Cahaya Manfaat. In Wirausaha Pendidikan Indonesia (Jilid 4). Sidoarjo: UNUSIDA Press.

Irawan, D. E., Purnomo, A., Sutiksno, D. U., Abraham, J., Alamsyah, A., Saputra, D. H., ,.. Rosyidah, E. (2018). Kajian Pendidikan Tinggi IDRI untuk DPR RI dan Ristek Dikti 2018. Bandung: ITB Press.

Iskandar, A., Rizal, M., Kurniasih, N., Sutiksno, D. U., \& Purnomo, A. (2018). The Effects of Multimedia Learning on Students Achievement in Terms of Cognitive Test Results. Journal of Physics: Conference Series, 1114(1), 012019. https://doi.org/10.1088/1742-6596/1114/1/012019

Johnson, J. (2019). How to Start a Profitable Online School in 5 Easy Steps. Retrieved December 9, 2019, from https://www.uscreen.tv/blog/how-to-startcreate-online-school/

Purnomo, A., Asitah, N., Rosyidah, E., Septianto, A., Daryanti, M. D., \& Firdaus, M. (2019). Generasi Z sebagai Generasi Wirausaha. https://doi.org/10.31227/osf.io/4m7kz

Purnomo, A., Putri, R. A., \& Rosyidah, E. (2017). Kamus Manajemen Sumber Daya Manusia. Sidoarjo: UNUSIDA Press.

Ray, H. (2015). 5 Easy Steps to Successfully Launch an Educational Startup. Retrieved December 10, 2019, from https://www.designhill.com/designblog/easy-steps-to-successfully-launch-an-educational-startup/

Setyawati, I., Purnomo, A., Irawan, D. E., Tamyiz, M., \& Sutiksno, D. U. (2018). A Visual Trend of Literature on Ecopreneurship Research Overviewed within The Last two Decades. Journal of Entrepreneurship Education, 21(4), 1-7. Retrieved from https://www.abacademies.org/articles/a-visual-trend-ofliterature-on-ecopreneurship-research-overviewed-within-the-last-twodecades-7468.html

Simarmata, J., Dharma, M., Putra Nasution, T., Manurung, R. T., Lubis, M. A., Kurniasih, N., ... Rahim, R. (2018). Prototype Application Multimedia Learning for Teaching Basic English. International Journal of Engineering \& Technology, 714(2), 264-266. https://doi.org/10.14419/ijet.v7i2.12.14689

Suci, S. H. A., Rosyidah, E., Asitah, N., Aini, N., Murni, A. W., Anam, F., ... Kuraesin, A. D. (2018). Learning from Picture and Picture Action Research: Enhancement of Counting Ability on Division of Numbers for Primary School Students. Journal of Physics: Conference Series, 1114(1), 012044. https://doi.org/10.1088/1742-6596/1114/1/012044

Sudrajat, D., Achdisty, M., Kurniasih, N., Roslina, Parwito, Mulyati, S., ... Sallu, S. (2019). The Implementation of Innovation in Educational Technology to Improve The Quality of Website Learning in Industrial Revolution Era 4.0 Using Waterfall Method. Journal of Physics: Conference Series, 1364, 012044. https://doi.org/10.1088/1742-6596/1364/1/012044 